\title{
Tasa-arvopolitiikka eriarvoisuuden poistamista
}

Nykyistä tasa-arvokeskustelua haittaa tasaarvo -käsitteen teoreettinen selkiytymättömyys. Tuntuu siltä, että tähän käsitteeseen asetetaan suunnittelun lähtökohtana joskus liikaakin odotuksia. Mikä tasa-arvolähtökohdan merkitys voisi olla aikuiskasvatuksen kehittämistyössä?

Allardt on eräässä artikkelissaan jakanut tasa-arvo -käsitteen aritmeettiseen ja suhteelliseen tasa-arvoon. Edellinen käsite tarkoittaa "täydellistä" tasa-arvoa kaikkien asioiden suhteen. Lienee selvää, että tällainen aritmeettinen tasa-arvo on eräänlainen utopia, jota ei voida koskaan saavuttaa. Ei edes Marxin kommunistisen yhteiskunnan utopia lähde tällaisesta tasa-arvonäkemyksestä. Siinäkin lähdetään periaatteesta, että "'jokaiselta kykyjensä mukaan, jokaiselle tarpeittensa mukaan'”. Lausuma kertoo jo sellaisenaan, että ihmiset ovat kyvyiltään ja tarpeiltaan erilaisia, ja heihin on näinollen myös suhtauduttava erilailla. Toisin sanoen on tunnustettava ihmisten erilaisuus inhimillisen olemassaolon erääksi keskeiseksi lähtökohdaksi.

Suhteellinen tasa-arvo taas tarkoittaa, että ihmisten tasa-arvoisuutta mitataan aina suhteessa johonkin asetettuun tavoitteeseen tai olemassa olevaan kriteeriin. Se on siis todella aina "suhteellinen". Samalla se on myös aina luonteeltaan historiallinen. Tämä merkitsee sitä, että historian kuluessa ihmisten käsitykset tasa-arvosta ovat muuttuneet ja muuttuvat epäilemättä edelleen. On ollut aikoja jolloin esim. kirkko on siunannut ihmisten eriarvoisuuden. Näin ei enää ainakaan virallisesti nykyisin tapahdu. Jokainen sukupolvi asettaa itse omat tasa-arvotavoitteensa. Ranskan vallankumouksen aikoihin tavoite tiivistyi poliittisen tasa-arvon vaatimukseen. Nykyisin se on yhä useammin asetettu myös taloudellista tasaarvoa koskevaksi.

On myös huomattava, että eri yhteiskuntaryhmillä saattaa olla erilainen näkemys tasa-arvosta ja sen merkityksestä. Tasa-arvo on siis mitä suurimmassa määrin myös yhteiskunnallinen kysymys. Sitä on käytetty ja käytetään poliittisen valtataistelun välineenä. Päiväkohtaisessa politiikassa yhä useammat elämänalueet on otettu tarkasteltavaksi tasa-arvon näkökulmasta. Tähän antaa perusteen se tosiasia, että yhteiskunnallista eriarvoisuutta on vaikea perustella eettisesti. Tosin tätäkin yritetään, nykyisin jopa yhä suuremmassa määrin. Tästä on osoituksena länsimaissa vilkkaana käytävä keskustelu sosiobiologismista, jossa ihmisten erilaisuuden perusteella yritetään perustella heidän eriarvoista kohteluaan. Humanistinen ajattelu, joka on länsimaisen ajattelun peruspilareita, lähtee kuitenkin siitä, että jokaiselle ihmiselle on yhtä lailla tunnustettava ihmisarvo.

Aikuiskoulutuksen johtoryhmä ei esittänyt muistiossaan tasa-arvon määritelmää. Koska tasa-arvo on, kuten edellä todettiin, suhteellinen käsite, ei sitä voidakaan ylihistoriallisesti täsmällisesti määritellä. Jos se halutaan määritellä jossakin historiallisessa tilanteessa, se täytyy määritellä negaationsa kautta, eli tarkastelemalla, mitkä seikat koetaan tietyssä historiallisessa vaiheessa sosiaalisena eriarvoisuutena. Tasa-arvon edistäminen aikuiskasvatuksessa merkitsee siis sellaisten nyky-yhteiskunnassa havaittavien eriarvoisuuksien poistamista, jotka ovat aikuiskasvatuksen keinoin mahdollisia. Mitä nämä eriarvoisuudet sitten ovat? Se on kiistanalaista. Jossain määrin niistä lienee mahdollista päästä sopimukseen. Tällaisina aikuiskasvatukseen liittyvinä eriarvoisuuksina on mainittu yleensä mm. sivistyksellinen, alueellinen, sukupuolten ja sukupolvien välinen sekä opistososiaalinen eriarvoisuus. Aikuiskasvatuksella voitaneen ainakin jossakin määrin vähentää em. eriarvoisuuksia. Sen sijaan esim. taloudellisen eriarvoisuuden poistaminen on tuskin mahdollista aikuiskasvatuksen keinoin, vaikka opiskelulla saattaa olla vaikutusta yksittäisen opiskelijan taloudelliseen asemaan. Kun tasa-arvoa halutaan edistää aikuiskasvatuksen avulla, on suunnittelijoiden pohdittava, mitkä seikat asettavat aikuiset ihmiset eriarvoiseen asemaan opintopalvelusten tavoitettavuuden, opintososiaalisen aseman ja oppimisen suhteen sekä lähdettävä pohtimaan niitä toi- 
menpiteitä, joilla näitä eriarvoisuutta aiheuttavia tekijöitä voidaan lieventää tai poistaa. Mitä eriarvoisuustekijöitä halutaan poistaa tai lieventää on siis pitkälle (aikuiskoulutus)poliittinen kysymys. Siitä miten vaikea tämä eriarvoisuuden poistaminen käytännössä saattaa olla, on osoituksena esim. opintovapaajärjestelmän jumiutuminen "palkattoman" opintovapaan tasolle. Kestänee kauan ennenkuin tässä maassa arvostetaan kaikkea opiskelua samalla tavoin ja kaikkien väestöryhmien opiskelua tuetaan samalla lailla, kuin tällä hetkellä esim. yritysten johtoportaan "'opinnollista"' osallistumista.

Eräs keskeinen ongelma tasa-arvon toteuttamisessa käytännössä on syntynyt nyky-yhteiskunnassa siitä, että meillä on vapaaehtoisuuteen perustuvan opiskelun rinnalle kehittynyt velvoiteluontoinen opiskelujärjestelmä. Tämä on luonteenomaista nimenomaan työelämän koulutustoiminnassa. Kun työnantajat järjestävät omalle henkilöstölleen koulutusta, niin valikointi ja osallistujien koulutustarpeen määrittely tapahtuu yleensä työnantajan toimesta. Työnantajan valintaperuste saattaa kuitenkin olla aivan joku muu, kuin tasaarvon edistäminen. Näin tasa-arvopolitiikan edistäminen työelämässä kohtaa työnantajien asenteisiin ja heidän lyhyen tähtäimen taloudellisiin etuihinsa liittyviä esteitä. Ongelmana on, miten aikuiskasvatuksen suunnitteluorganisaatio voi vaikuttaa työnantajien asenteiden muuttamiseen tasa-arvoisempaan suuntaan? Ainakaan tällä hetkellä tilanne ei näytä valoisalta, sillä työnantajien koulutustoiminnan keskeisimpänä lähtökohtana ovat taloudelliset edut ja tehokkuuden lisääminen. 